Gulawentah: Jurnal Studi Sosial

ISSN 2528-6293 (Print); ISSN 2528-6871 (Online)

Vol. 6, No. 1, Juni 2021, Hal 69-76

Tersedia Online: http://e-journal.unipma.ac.id/index.php/gulawentah

\title{
Analisis peran ASEAN dalam proses unifikasi Semenanjung Korea
}

\author{
Alfredo Yowel Antaribaba ${ }^{*}$, Agus Salim ${ }^{1}$, J Jumino' \\ ${ }^{1}$ Sekolah Staf dan Komando Angkatan Laut, Kota Jakarta Selatan, Indonesia \\ Email: boykeronsumbre@gmil.com*; guslim_msaka@yahoo.com; jumino9945@gmail.com
}

Naskah diterima: 10/05/2021; Revisi: 20/06/2021; Disetujui: 24/06/2021

\begin{abstract}
Abstrak
Setelah Perang Korea berakhir membuat Selatan dan Utara menjadi terpisah. Kedua negara tidak serta menjadi damai bahkan terus terjadi eskalasi tensi di kawasan. Eskalasi tensi di Semenanjung Korea meningkat ketika Korea Utara dengan sengaja melakukan proliferasi nuklir dan adanya peningkatan uji coba rudal Korea Utara. Hal ini kemudian diimbangi dengan adanya Terminal High Altitude Area Defense (THAAD) oleh Korea Selatan. Kerjasama militer dan joint exercise antara Amerika Serikat dan Korea Selatan juga menimbulkan tensi yang kuat di kawasan semenanjung. Tujuan penelitian ini yakni menganalisis dinamika konflik di kawasan Semenanjung Korea dari era Sunshine Policy pada tahun 1998 hingga tahun 2020 (New Southern Policy) dengan pendekatan unifikasi melalui keamanan regional. Metode yang digunakan dalam penelitian ini adalah kualitatif dengan desain penelitian deskriptif analisis untuk memberikan gambaran secara tepat mengenai keadaan di kawasan tersebut. Peneliti menganalisis penyelesaian konflik di Semenanjung Korea dengan Regional Security Complex Theory (RSCT). Dari penelitian tersebut, peneliti menyimpulkan bahwa entitas aktor lain di kawasan, ASEAN, dapat menjadi membantu dan memfasilitasi penyelesaian masalah.
\end{abstract}

Kata kunci: semenanjung Korea; unifikasi; RSCT; ASEAN

\section{Analysis of the role of ASEAN in the unification prosess of The Korean Peninsula}

\section{Abstract}

Following the end of the Korean War, the South and North were divided. The two nations did not become peaceful, and instead heightened tensions in the area. The escalation of tensions on the Korean Peninsula accelerated as North Korea actively conducted nuclear proliferation and increased its missile testing. his was then offset by the existence of Terminal High Altitude Area Defense (THAAD) by South Korea. Military cooperation and joint exercises between the United States and South Korea have also created strong tensions in the peninsula. The aim of this research is to examine the dynamics of conflict in the Korean Peninsula region from the Sunshine Policy era in 1998 to 2020 (New Southern Policy) using a unification strategy through regional security. To offer an accurate picture of the situation in the area, the research approach employed in this study is qualitative with descriptive analytic research design. Using the Regional Security Complex Theory (RSCT), researchers examined conflict resolution on the Korean Peninsula. From this research, the researchers concludes that another actor entity in the region, ASEAN, can be helpful and facilitate problem solving.

Keywords: Korean peninsula; unification; RSCT; ASEAN

DOI: 10.25273/gulawentah.v6i1.9597

Some rights reserved. 


\section{Pendahuluan}

Perang Korea dimulai pada 25 Juni 1950 yang ditandai dengan Korea Utara bersama Uni Soviet menginvasi wilayah Selatan yang pro Barat. Perang tersebut berakhir pada 1953 dengan kurang lebih 5 juta tentara dan rakyat sipil tewas (Iqbal, 2010). Akibat dari perang tersebut membuat kedua Korea terpisah hingga saat ini. Korea Utara dan Korea Selatan terpisah sebagai hasil kesepakatan Amerika Serikat dan Rusia di akhir Perang Dunia II. Keduanya resmi terpisah di sebuah garis yang disebut garis 38 derajat atau yang dikenal dengan demilitarized zone (DMZ). Sejak kedua negara menyepakati adanya gencatan senjata pada tahun 1953, meskipun telah dicapai kesepakatan damai, seperti July 4, 1972, Joint Communiqué between North Korea and South Korea dan Joint Declaration 15 June 2000 antara dua pemimpin tertinggi Korea saat itu, namun konflik masih terus berlangsung. Hal ini terlihat dari intensitas dan tindakan propaganda Korea Utara yang cukup tinggi (Oh \& Hassig, 2021).

Upaya menuju reunifikasi Korea telah dirintis oleh Presiden Korea Selatan, Kim Dae Jung dengan mengadakan pertemuan antar negara Korea dalam rangka membentuk Sunshine Policy pada tahun 1998. Pertemuan dan kebijakan yang diusulkan Korea Selatan mendapat sambutan hangat dari Korea Utara sebagai bentuk timbal balik bantuan Korea Selatan. Pertemuan ini dilanjutkan dalam pertemuan Konferensi Tingkat Tinggi (KTT) antar Korea yang diadakan pada tahun 2000. Rencana KTT Korea ini untuk membicarakan lebih serius ke arah reunifikasi Korea. Hubungan antar-Korea berlanjut semakin membaik melalui Sunshine Policy yang dipelopori Presiden Korea Selatan, Kim Dae Jung pada tahun 1998. Pada masa pemerintahan Presiden Kim Daejung (1998-2003) terjadi peningkatan hubungan Korea Utara-Korea Selatan. Melalui sebuah kebijakan yang terkenal dengan nama Sunshine Policy atau Kebijakan Matahari Terbit, Korea Selatan melakukan pendekatan secara tidak langsung dengan Korea Utara dalam proses menuju reunifikasi (Min, 2017). Meskipun upaya-upaya tersebut telah dilakukan, proses unifikasi masih terhambat.

Upaya untuk meyakinkan Republik Rakyat Demokratik Korea (DPRK atau Korea Utara) untuk meninggalkan aspirasi dan program senjata nuklirnya telah terjebak dalam siklus resolusi konflik yang bersifat "cuci-bilas-ulang" yang berlangsung selama tiga dekade terakhir. Berbagai langkah-langkah yang dinegosiasikan dengan hati-hati dan proses yang telah dipimpin oleh para ahli gagal untuk bertahan dari rintangan politik yang tak terhindarkan, kemunduran teknis, dan saling tudingyang berumur pendek. Berbagai uji coba ledakan nuklir dan peluncuran rudal balistik oleh DPRK adalah bukti positif bahwa metode baru, berdasarkan logika yang berbeda, diperlukan untuk mencapai denuklirisasi Semenanjung Korea dan diluar terbentuknya zona bebas senjata nuklir di Asia Timur Laut (Nuclear-Weapon-Free Zone In Northeast Asia I NEANWFZ) (Dalton, 2020).

Eskalasi krisis di Semenanjung Korea meningkat ketika DPRK dengan sengaja melakukan proliferasi nuklir di kawasan Semenanjung Korea. Selain itu terdapat beberapa aksi lain yang dianggap sebagai tindakan yang dapat mengancam stabilitas keamanan di semenanjung ini, antara lain adanya peningkatan uji coba rudal Korea Utara dan Terminal High Altitude Area Defense (THAAD) milik Korea Selatan. Namun di sisi lain untuk mengimbangi kemajuan rudal Korea Utara, Terminal High Altitude Area Defense (THAAD) digunakan Korea Selatan sebagai bentuk sistem pertahanan rudal milik Amerika Serikat untuk memastikan langkah pertahanan keamanan bagi Korea Selatan. Sebelumnya THAAD merupakan singkatan dari Theater Altitude Area Defense yang merupakan sistem peluru kendali (rudal) antibalistik Angkatan Darat 
Amerika Serikat yang dirancang untuk menembak jatuh rudal jarak dekat, sedang, dan menengah dengan menggunakan pendekatan mencegat rudal musuh dengan tembakan langsung (hit-to-kill) (Mehta, 2016). Selain itu, konflik di Semanjung meningkat selama latihan bersama antara pasukan Korea Selatan dan Amerika. Lebih dari 28.000 tentara Amerika Serikat ditempatkan di Korea Selatan untuk berjaga-jaga terhadap ancaman dari Korea Utara. Pemerintah Korea Selatan telah menyatakan kesediaannya untuk membayar lebih bagi militer Amerika Serikat untuk tinggal di Korea Selatan. Seperti yang kita semua tahu, kedua negara telah menjadi sekutu keamanan sejak Perang Korea 1950-1953. Perang Korea berakhir dengan gencatan senjata daripada perjanjian damai. Kementerian Luar Negeri Korea Selatan membayar sekitar 1,04 triliun won atau sekitar 12,9 triliun rupiah pada tahun 2019. Ini merupakan peningkatan sekitar 8,2\% dari 960 miliar won yang diberikan dalam perjanjian untuk lima tahun pertama pada 2018. Kesepakatan tersebut akhirnya melalui negosiasi yang panjang, dan kedua negara menerapkan kesepakatan yang hanya berlaku setahun sekali (Utomo, 2021).

Dewasa ini, para pengamat dan analis mulai mempelajari lebih lanjut proses resolusi konflik di Semenanjung Korea dengan menggunakan rezim perdamaian, termasuk opsi dan pendekatan yang masuk akal dari gencatan senjata saat ini ke perjanjian perdamaian baru (Aum et al., 2020). Dalam jangka panjang, beberapa penelitian bahkan mengandaikan adanya pengembangan kemitraan keamanan (Halperin et al., 2018). Ide-ide ini harus melibatkan pembentukan struktur untuk menghilangkan atau setidaknya melibatkan berbagai aktor netral dalam membantu.

\section{Metode Penelitian}

Dalam penelitian ini, metode yang digunakan adalah pendekatan kualitatif guna memahami fenomena yang dialami subyek antara lain persepsi, perilaku, motivasi, serta tindakan secara keseluruhan dalam bentuk kata-kata atau bahasa (Moleong, 2007). Penelitian ini menggunakan desain penelitian deskriptif analisis dengan tujuan untuk memberikan gambaran secara tepat mengenai individu, kelompok atau keadaan tertentu terkait gejala-gejala yang ada dan terjadi. Penelitian ini akan melihat dinamika tensi di Semenanjung Korea pasca Perang Korea, serta menganalisis resolusi konflik dalam rangka meminimalisasi konflik di kawasan dari era Sunshine Policy pada tahun 1998 hingga tahun 2020 (New Southern Policy). Teknik analisa data yang akan dilakukan dalam penelitian ini adalah melalui analisa interaktif yang dikemukakan (Creswell \& Creswell, 2017). Adapun tahapan-tahapan dalam analisis data yang dikemukakan Creswell, yaitu mengolah data, membaca keseluruhan data, menganalisis data secara detail, menghubungkan deskripsi, dan menginterpretasikan deskripsi (Creswell \& Creswell, 2017; Gregar, 1994)

\section{Hasil dan Pembahasan}

Buzan et al. (2003) mengemukakan Regional Security Complex Theory (RSCT). RSCT didefinisikan sebagai berikut:

"a set of units whose major processes of securitisation, desecuritisation, or both are so interlinked that their security problems cannot reasonably be analysed or resolved apart from one another." 
Pendekatan pada teori ini memiliki kemiripan dengan pendekatan neo-realisme. Pendekatan RSCT biasanya digunakan untuk membahas regional-regional yang ada di dunia secara khusus di kawasan Asia Timur dan Asia Tenggara. Pendekatan teori ini tidak jauh berbeda dengan teori yang dikemukakan oleh Buzan pada Peoples, States, and Fear. Perbedaan mendasar pada pengertian ini adalah hilangnya fokus Negara menjadi Unit. Perubahan ini adalah bentuk pengakuan bahwa aktor yang berperan pada konteks sekuritisasi dan desekuritisasi dapat berasal dari aktor-aktor non-negara (Buzan et al., 2003).

Konteks RSCT memiliki keterkaitan antara aktor dalam kawasan regional dimana hal tersebut merupakan hal yang sangat penting. RSCT mampu menangkap fenomena pergeseran fokus keamanan ke arah yang mengacu pada skala regional maupun sub-regional. Selain itu, teori ini dapat dikatakan mampu menjadi sarana dalam memahami dinamika kekuatan dalam sebuah kawasan sehingga dengan demikian mampu juga dikaji mengenai dilema keamanan (security dilemma) dengan lebih konkret dan lebih luas (Agung et al., 2006). Peneliti lain, Richard Stubbs, menegaskan pengaruh RSCT dalam memahami konteks keamanan regional dimana kepemimpinan pada konteks ini adalah proses suatu negara atau kelompok negara pada sebuah sistem internasional guna memfasilitasi mekanisme penyelesaian masalah (Stubbs, 2014).

Pada konteks keamanan di kawasan Semenanjung Korea, negara-negara kuat seperti Amerika Serikat ikut terlibat dalam isu di Semenanjung Korea diantara negaranegara middle powers yang berkonflik, Korea Selatan dan Korea Utara. Tensi Semenanjung Korea semakin kompleks dikarenakan penempatan Terminal High Altitude Area Defense (THAAD) yang digunakan Korea Selatan sebagai sistem pertahanan rudal rudal milik Amerika Serikat untuk memastikan langkah pertahanan keamanan bagi Korea Selatan. Aksi penempatan ini merupakan bentuk balancing terhadap aktivitas Korea Utara yang dengan sengaja melakukan proliferasi nuklir dikawasan Semenanjung Korea. Amerika Serikat juga tetap mempertahankan aktivitas dengan sekutunya Korea Selatan dengan penempatan tentaranya dan latihan perang bersama.

Berdasarkan penjelasan dari Sun Chull Kim dari Seoul National University menjelaskan bahwa aliansi pertahanan Amerika Serikat dan Korea Selatan merupakan bentuk kerjasama militer yang telah berada pada level untuk melaksanakan joint exercise guna membuat DPRK tenang dan berusaha untuk mengurangi aktivitas nuklir dan misilnya. Tujuan ini tentu tidak lepas untuk mengurangi tensi di Semenanjung Korea. Hal ini dikarenakan Korea Selatan juga telah membayar dengan biaya cukup mahal untuk mengurangi tensi di Semenanjung Korea dengan menjalin komitmen dengan Amerika Serikat melalui joint exercise tersebut (Moon, 2015; Sari, 2020)

Selain itu, Korea Selatan juga menggunakan pendekatan kepada negara-negara lain yang berada dekat dengan kawasan. Pemerintah Korea Selatan telah lama memfokuskan arah kebijakan strategisnya pada negara-negara Asia Tenggara, termasuk di dalamnya organisasi ASEAN. Korea Selatan di bawah pemerintahan konsultatif cenderung mengeluarkan kebijakan yang bersifat hard power. Korea Selatan cenderung mencari dukungan dari negara anggota ASEAN dalam memberikan hukuman serta menekan Korea Utara. Namun di bawah pemerintahan progresif, Korea Selatan lebih mengedepankan pada engagement dan dialog dengan Korea Utara yang mulai intens dilakukan pada masa administrasi Presiden Moon Jae In. Pada masa administrasi Presiden Moon juga dikeluarkan sebuah kebijakan strategis baru, yang bernama " $\mathrm{New}$ Southern Policy" di mana kebijakan tersebut mengedepankan hubungan dengan 
ASEAN terhadap isu Semenanjung Korea dan Presiden Moon berupaya untuk mengedepankan peran ASEAN dalam upaya unifikasi Korea. Adanya keterlibatan forum regional tersebut kemudian memicu pemerintah Korea Selatan yang selama ini hanya fkus pada keamanan di kawasan Semenanjung Korea secara spesifik(Oh \& Hassig, 2021). Tujuan utama Presiden Moon mengeluarkan kebijakan New Southern Policy adalah untuk mengimbangi 4 major power yang memiliki kepentingan di Semenanjung Korea, yakni Amerika Serikat, Rusia, China dan Jepang. Dibentuknya New Southern Policy ini juga memiliki beberapa alas an (Jaehyon, 2019):

1. Memperbaiki bias kebijakan luar negeri. Korea Selatan selama ini hanya memfokuskan kebijakan luar negerinya guna menghadapi ancaman dari Korea Utara, dan cenderung mengabaikan berbagai isu keamanan lainnya yang mulai berkembang. Hal ini dipengaruhi juga oleh kehadiran 4 major power di kawasan Semenanjung Korea. Kebijakan Korea Selatan yang seperti ini justru tidak akan menimbulkan kemajuan bagi Korea Selatan. Pemerintahan Korea Selatan harus merefleksikan realitas bahwa ASEAN menempati peringkat ke-2 sebagai mitra kerja sama Korea Selatan. Posisi tersebut mengalahkan Rusia dan Jepang sebagai major power di Semenanjung Korea.

2. Mengimbangi kompetisi negara super power. Perang dagang yang terjadi antara Amerika Serikat dan China secara spesiik mampu mempengaruhi Korea Selatan. Dalam bidang pertahanan, Korea Selatan, sebagai aliansi Amerika Serikat di kawasan, bergantung pada berbagai kekuatan yang dikirimkan oleh Amerika Serikat, salah satunya THAAD. Hal ini mampu mengancam kepentingan nasional China, sehingga mempengaruhi hubungan ekonomi China dan Korea Selatan. Dalam hal ini, Korea Selatan mulai mengurangi ketergantungan ekonominya terhadap China dan memperluas jaringan kerja sama

3. Kontribusi Korea. Sebagai negara yang tergolong kategori middle power, Korea belum pernah memberikan kontribusi apapun pada masyarakat internasional. Oleh karena itu, Korea Selatan sebagai negara middle power yang memilkiki kekuatan di biang ekonomi dan diplomasi menggunakan New Southern Policy ini untuk memberikan kontribusi pada masyarakat ASEAN, melalui kesejahteraan ekonomi.

4. New Southern Policy sebagai bagian dari difersifikasi diplomasi yang dilakukan oleh Korea.

Salah satu upaya untuk menjalankan New Southern Policy, Korea Selatan menajalankan strategi 3Ps (People, Prosperity, Peace). Dalam hubungan diplomatik, terdapat 3 bidang fundamental, politik dan keamanan; ekonomi; serta sosial budaya. Strategi people-to-people diplomacy yang dijalankan oleh Korea Seatan ini bagian dari upaya hubungan diplomatic yang dikembangkan dalam bidang sosial-budaya (Baskoro, 2017; Shertina \& Utomo, 2021). Namun jika berbicara mengenai keamanan, merupakan isu yang sensitif bagi setiap negara. Keamanan juga erat kaitannya dengan pertahanan, karena keamanan dan pertahanan meyangkut kedaulatan negara. Permasalahan yang dihadapi dalam kerjasama keamanan dan pertahanan antara Korea Selatan dan ASEAN adalah belum adanya kesamaan persepsi megenai ancaman bersama. Bagi Korea Selatan, Korea Utara adalah ancaman nomor satu yang harus dihadapi. Sedangkan bagi ASEAN, Korea Utara bukan ancaman yang harus dihadapi langusung. Hal ini kemudian menjadi salah satu upaya pedamaian yang harus dibentuk antara Korea Selatan dan ASEAN. 
Pada pertemuan EAS dan Shangrilla Forum, Korea Utara telah terlibat dalam pertemuan sejak tahun 2010. Indonesia dan ASEAN sebenarnya telah diminta bantuan oleh Korea Selatan namun tidak semua anggota ASEAN berpikiran yang sama untuk terlibat dalam upaya negosiasi antara Korea Selatan dan Korea Utara. ASEAN memiliki banyak forum dan dialog yang dapat diinisiasi untuk menjembatani kedua Negara tersebut. Lee Jaehyon dari The ASAN Institute for Policy Studies menjelaskan bahwa ASEAN dapat berperan sebagai aktor yang berguna untuk memfasilitasi mekanisme penyelesaian masalah antara Korea Selatan dan Korea Utara. Hal ini disampaikan Korea Selatan dalam pertemuan ke-22 ASEAN-Korea Selatan yang berlangsung di Seoul kepada negara-negara ASEAN, termasuk Indonesia, untuk membantu proses perdamaian di Semenanjung Korea (Jaehyon, 2019).

Berdasarkan teori RSCT, konteks keamanan regional di Semenanjung Korea dimana kepemimpinan pada konteks ini adalah proses mengurangi tensi dapat dilakukan oleh ASEAN sebagai organisasi regional. Kondisi internasional yang tidak stabil pasca Perang Dingin memberikan fenomena terhadap regional Asia khususnya kawasan Semenajung Korea. Negara-negara di Asia Tenggara dan diluar kawasan mulai mengarahkan fokus pada perkembangan sekitar dimana kondisi ini menambah kompleksitas keamanan kawasan di kawasan (Agung et al., 2006). Pada konteks keamanan di kawasan Semenanjung Korea, negara-negara sekitar seperti anggota ASEAN dapat ikut terlibat dalam memperjuangkan kepentingan diantara negara-negara middle powers yang berkonflik, Korea Selatan dan Korea Utara.

Kompleksitas di kawasan ini semakin diperjelas dengan adanya peningkatan kekuatan militer khususnya dalam senjata nuklir. Senjata nuklir ditujukan sebagai strategi untuk mengimbangi lawan-lawan yang dinilai memiliki kemampuan militer yang lebih baik. Pengembangan senjata nuklir Korea Utara memberikan implikasi terhadap kompleksitas keamanan kawasan di Semanjung. Korea Utara meyakini senajata nuklir akan dapat menangkal serangan Amerika Serikat dan membuat negaranya lebih kuat daripada Korea Selatan. Melalui teori RSCT dijelaskan juga bahwa security complex sebagai sebuah tahapan lanjut dalam memahami konteks pergeseran kekuasaan ke arah regionalisme dan bagaimana kekuasaan diterjemahkan dan dipersepsikan oleh regional (Buzan et al., 2003). Teori ini menunjukkan bahwa kompleksitas keamanan kawasan di Semanjung Korea terlihat dari pengembangan senjata nuklir Korea Utara sehingga sulitnya proses reunfikasi dan pengurangan tensi konflik di kawasan.

Berdasarkan pemaparan di atas, peneliti menganalisis bahwa sebuah sistem dapat membantu proses reunifikasi yang sedang dilakukan oleh Korea Selatan dan Korea Utara sebagai bentuk mencapai perdamaian dan stabilitas di Semenanjung Korea adalah dengan mengacu pada dukungan dari organisasi regional seperti ASEAN. Konsep kepentingan nasional menjadi konsep yang akan menganalisis strategi negara sebagai aktor utama yang memiliki bargaining position dalam melakukan kerjasama untuk mencapai kepentingan nasionalnya. Kerjasama sendiri menjadi salah satu instrumen yang menunjukkan peran aktor dalam memberikan pengaruhnya demi mencapai kepentingan nasional. Proses reunifikasi sendiri tidak hanya mengakomodasi kepentingan aktor yang terlibat saja yaitu Korea Utara dan Korea Selatan, akan tetapi dalam pelaksanaannya kemudian muncul aktor lain yang ikut melibatkan diri, terutama ASEAN. 


\section{Simpulan}

Akibat dari Perang Korea telah membuat kedua Korea terpisah hingga saat ini. Namun konflik masih terus berlanjut hingga saat ini diantara kedua negara tersebut. Eskalasi tensi di Semenanjung Korea meningkat ketika Korea Utara dengan sengaja melakukan proliferasi nuklir di kawasan Semenanjung Korea. Selain itu terdapat beberapa aksi lain yang dianggap sebagai tindakan yang dapat mengancam stabilitas keamanan di semenanjung ini, antara lain adanya peningkatan uji coba rudal Korea Utara dan Terminal High Altitude Area Defense (THAAD) untuk mengimbangi kemajuan rudal Korea Utara, Terminal High Altitude Area Defense (THAAD). Kerjasama militer dan joint exercise antara Amerika Serikat dan Korea Selatan juga menimbulkan tensi yang kuat di kawasan semenanjung. Berdasarkan penjelasan Regional Security Complex Theory bahwa konteks keamanan regional dapat diupayakan oleh negara dan sekelompok negara untuk menyelesaikan masalah kawasan. Teori ini menunjukkan bahwa kompleksitas keamanan kawasan di Semanjung Korea terlihat dari pengembangan senjata nuklir Korea Utara sehingga sulitnya proses reunfikasi dan pengurangan tensi konflik di kawasan. ASEAN yang merupakan salah satu organisasi di regional yang setelah beberapa dekade juga terbukti aktif dalam menjaga stabilitas keamanan dapat menjadi salah satu aktor yang berperan untuk mengurangi tensi di kawasan Semenanjung Korea.

\section{Daftar Pustaka}

Agung, A., Perwita, B., \& Yani, Y. M. (2006). Pengantar Ilmu Hubungan Internasional. Bandung: PT Remaja Rosdakarya.

Aum, F., Stokes, J., Kim, P. M., Trivedi, A. M., Vandenbrink, R., Staats, J., \& Yun, J. Y. (2020). a Peace regime for the Korean Peninsula. United States Institute of Peace Washington, DC.

Baskoro, R. M. (2017). Konseptualisasi dalam Gastro Diplomasi: Sebuah Diskusi Kontemporer dalam Hubungan Internasional. Insignia: Journal of International Relations, 4(02), 35-48. http://jurnalonline.unsoed.ac.id/index.php/insignia/article/download/666/496

Buzan, B., Buzan, B. G., W'ver, O., Waever, O., \& Buzan, O. W. B. (2003). Regions and powers: the structure of international security. Cambridge University Press.

Creswell, J. W., \& Creswell, J. D. (2017). Research design: Qualitative, quantitative, and mixed methods approaches. Sage publications.

Dalton, T. (2020). From Deterrence to Cooperative Security on the Korean Peninsula. Journal for Peace and Nuclear Disarmament, 3(1), 144-156. https://doi.org/https://doi.org/10.1080/25751654.2020.1747907

Gregar, J. (1994). Research Design (Qualitative, Quantitative and Mixed Methods Approaches). Book published by SAGE Publications, 228. 
Halperin, M., Hayes, P., Pickering, T., Sigal, L., \& Yun, P. (2018). From Enemies to Security Partners: Pathways to Denuclearization in Korea. Nautilus Peace and Security Network Net Policy Forum,

Iqbal, A. (2010). Perang Perang Paling Berpengaruh Didunia. Jogja Bangkit Publisher.

Jaehyon, L. (2019). Korea's New Southern Policy: Motivations of 'Peace Cooperation'and Implications for the Korean Peninsula. The Asian Institute for Policy Studies Issue Brief, 1-19. https://www.jstor.org/stable/pdf/resrep20678.pdf

Mehta, A. (2016). PACOM Head Supports Exercises Near China, Talks THAAD. DefenseNews. https://www.defensenews.com/naval/2016/02/25/pacom-headsupports-exercises-near-china-talks-thaad/

Min, J. (2017). The Sunshine Policy of South Korea. Stanford University.

Moleong, L. J. (2007). Metode penelitian kualitatif. Bandung: Remaja Rosdakarya.

Moon, K. H. (2015). South Korea's demographic changes and their political impact. East Asia Policy Paper, 6(10), 1-7.

Oh, K., \& Hassig, R. (2021). North Korea in a Nutshell: A Contemporary Overview.

Sari, I. G. M. (2020). Penerapan the Policy of Peace and Prosperity Dalam Upaya Reunifikasi Korea Selatan dengan Korea Utara Periode 2017-2108.

Shertina, R., \& Utomo, A. B. (2021). Strategi Gastrodiplomasi Pemerintah Korea Selatan Dalam Program Global Hansik Campaign Di Indonesia Pada Tahun 2012-2017. Al Qodiri: Jurnal Pendidikan, Sosial dan Keagamaan, 19(1), 187201.

Stubbs, R. (2014). ASEAN's leadership in East Asian region-building: strength in weakness. The Pacific Review, 27(4), 523-541. https://doi.org/https://doi.org/10.1080/09512748.2014.924229

Utomo, A. P. (2021). Korea Selatan Sepakat Bayar Ongkos Penempatan Pasukan AS di Negaranya. Kompas. https://www.kompas.com/global/read/2021/03/08/140928170/korea-selatansepakat-bayar-ongkos-penempatan-pasukan-as-di-negaranya?page=all 